\title{
AM(VI) PARTITIONING STUDIES: FY14 FINAL REPORT
}

\author{
Bruce J. Mincher
}

October 2014

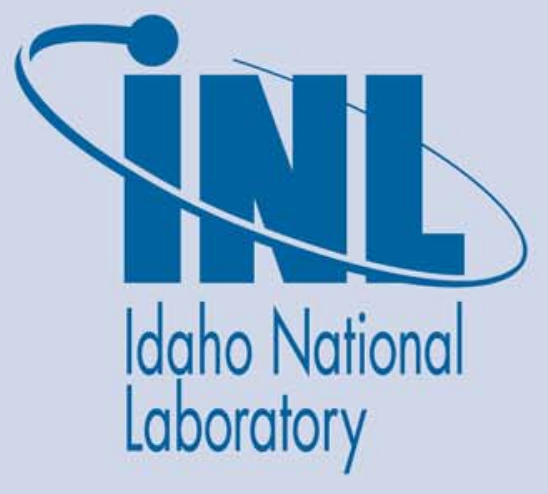

The INL is a U.S. Department of Energy National Laboratory operated by Battelle Energy Alliance 
INL/EXT-14-33297

\title{
AM(VI) PARTITIONING STUDIES: FY14 FINAL REPORT
}

\author{
Bruce J. Mincher
}

October 2014

\section{Idaho National Laboratory \\ Idaho Falls, Idaho 83415}

http://www.inl.gov

\author{
Prepared for the \\ U.S. Department of Energy \\ Office of Nuclear Enegyr \\ Under DOE Idaho Operations Office \\ Contract DE-AC07-05ID14517
}


Am(VI) Partitioning

Studies: FY14 Final

Report

Fuel Cycle Technology

Prepared for

U.S. Department of Energy Sigma Team for Minor Actinide Separations Bruce J. Mincher Idaho National Laboratory Date FCRD-SWF-2014-000630 



\section{DISCLAIMER}

This information was prepared as an account of work sponsored by an agency of the U.S. Government. Neither the U.S. Government nor any agency thereof, nor any of their employees, makes any warranty, expressed or implied, or assumes any legal liability or responsibility for the accuracy, completeness, or usefulness, of any information, apparatus, product, or process disclosed, or represents that its use would not infringe privately owned rights. References herein to any specific commercial product, process, or service by trade name, trade mark, manufacturer, or otherwise, does not necessarily constitute or imply its endorsement, recommendation, or favoring by the U.S. Government or any agency thereof. The views and opinions of authors expressed herein do not necessarily state or reflect those of the U.S. Government or any agency thereof. 



\section{SUMMARY}

The use of higher oxidation states of americium in partitioning from the lanthanides is under continued investigation by the sigma team. This is based on the hypothesis that Am(VI) can be produced and remain stable in irradiated first cycle raffinate solution long enough to perform solvent extraction for separations. The stability of Am(VI) to autoreduction was measured using millimolar americium concentrations in a 1-cm cell with a Cary $6000 \mathrm{UV} / \mathrm{V}$ is spectrophotometer for data acquisition. At millimolar americium concentrations, Am(VI) is stable enough against its own autoreduction for separations purposes. A second major accomplishment during FY14 was the hot test. Americium oxidation and extraction was performed using a centrifugal contactorbased test bed consisting of an extraction stage and two stripping stages. Sixty-three percent americium extraction was obtained in one extraction stage, in agreement with batch contacts. Promising electrochemical oxidation results have also been obtained, using terpyridine ligand derivatized electrodes for binding of Am(III). Approximately $50 \%$ of the Am(III) was oxidized to $A m(V)$ over the course of 1 hour. It is believed that this is the first demonstration of the electrolytic oxidation of americium in a non-complexing solution. Finally, an initial investigation of Am(VI) extraction using diethylhexylbutyramide (DEHBA) was performed. 


\section{CONTENTS}

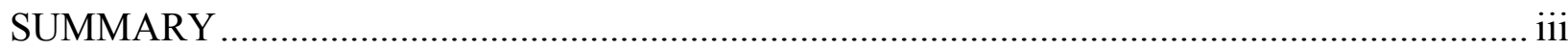

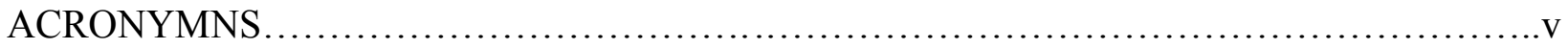

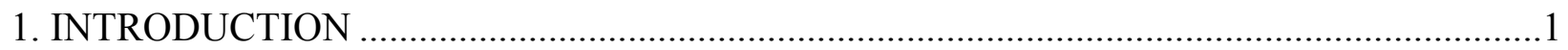

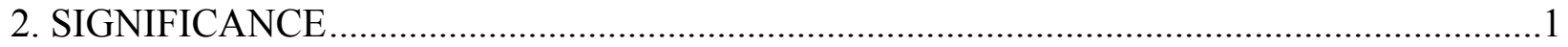

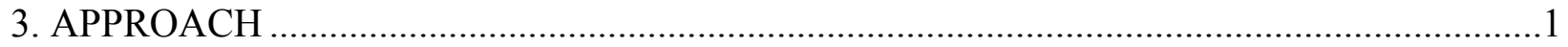

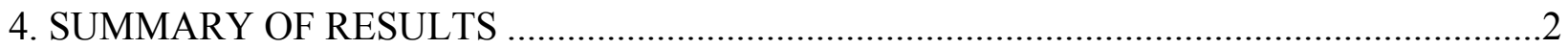

4.1 Hexavalent Americium

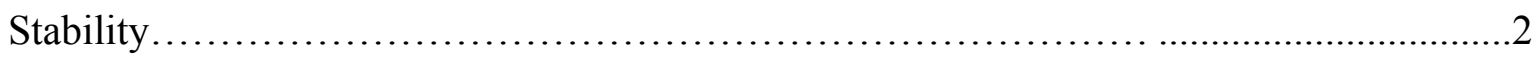

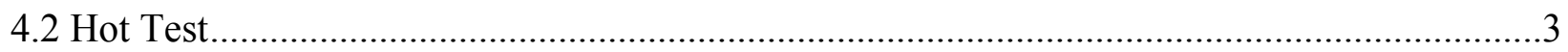

4.3 Americium Electrochemistry …………………...............................................................

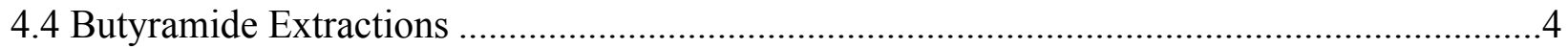

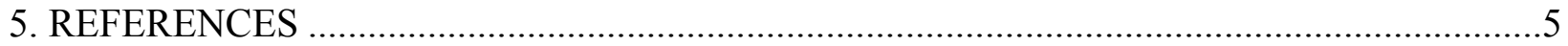

6. PUBLICATIONS AND OTHER INDICATORS OF PROJECT QUALITY AND

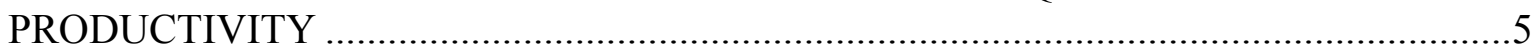

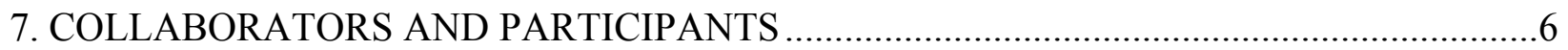

\section{FIGURES}

Figure 1. The autoreduction of $\mathrm{Am}(\mathrm{VI})$ in a $6.5 \mathrm{M} \mathrm{HNO}_{3}$ solution containing $2 \times 10^{-3} \mathrm{M}$ total Am, based on the absorbance measured for $\mathrm{Am}(\mathrm{VI})$ at $666 \mathrm{~nm}$ (closed diamonds), in a 1-cm cell using the Cary 6000. Rate constant based on the mean of linear fit for the entire data set is 0.004 $\mathrm{h}^{-1}$. Using the fit to only the first ten hours a rate constant of $0.005 \mathrm{~h}^{-1}$ was obtained. .............

Figure 2. Radiochemical hood showing the three-stage centrifugal-contactor test bed, simulant feed reservoir and bismuthate filter. Note: The system was photographed prior to taking it hot and therefore, there are no Contamination Area postings on the hood. 


\section{ACRONYMS}

CFA Central Facilities Area

CINC Costner Industries Nevada Corporation

DAAP Diamylamylphosphonate

DEHBA Diethylhexylbutyramide

DEHiBA Diethylhexylisobutryamide

FTO Fluoride-doped tin oxide

GANEX Group actinide extraction

INL Idaho National Laboratory

LWCC Liquid waveguide capillary cell

$n$-ITO Nano-indium tin oxide

TBP Tributylphosphate

UNC University of North Carolina

UV/Vis Ultraviolet/visible spectroscopy 



\section{AM(VI) PARTITIONING STUDIES: FY14 FINAL REPORT}

\section{INTRODUCTION}

The use of higher oxidation states of americium in partitioning from the lanthanides is under continued investigation by the Sigma Team for Minor Actinide Separation. This is based on the hypothesis that Am(VI) can be produced and remain stable in irradiated first cycle raffinate solution long enough to perform solvent extraction for separations. Our previous work has characterized the DAAP extraction of $\mathrm{Am}(\mathrm{VI})$ and the behavior of the lanthanides and other common fission products and inert constituents under the same conditions (Mincher et al. 2012). This work has allowed us to begin investigation of flowsheet concepts for such a separation (Law et al. 2014). Ideally, co-extraction of hexavalent $\mathrm{Np}, \mathrm{Pu}$, and $\mathrm{Am}$ could be performed simultaneously, on the raffinate from a prior uranium extraction process. The objectives of FY14 work, based on the assigned milestones were:

1. Examine the stability of produced $A m(V I)$ under various solution conditions by examination of reduction kinetics.

2. Modify the proposed flowsheet as necessary, and run a hot test to perform americium oxidation and extraction under test bed conditions.

3. Continue collaborative research with UNC-Chapel Hill on electrolytic americium oxidation.

The most important expectation for the FY14 work was to demonstrate an understanding of Am(VI) stability well enough to support the hot test.

\section{SIGNIFICANCE}

The separation of americium from the lanthanides is desirable to facilitate incorporation of americium in fast reactor fuel for transmutation purposes. Development of a process to separate americium based on its oxidation state has the potential to greatly simplify current flowsheets. If americium were extracted as Am(VI) from the nitric acid concentrations typical of fuel cycle separations, selective stripping of lanthanides (III) would no longer be necessary. Further, a GANEX-type co-extraction of all the actinides from oxidized solution is readily envisioned.

\section{APPROACH}

In past unpublished work on this program, the stability of Am(VI) varied depending on experimental conditions. Therefore, a thorough examination of the autoreduction of Am(VI) under solution conditions of interest to fuel cycle separations was initiated in FY14. The first work describing the autoreduction of the higher oxidation states of americium was reported by Asprey and Stephanou (1950). It was shown that Am(VI) reduced to Am(V) in linear fashion with respect to time, following which $\mathrm{Am}(\mathrm{V})$ reduced in linear fashion to Am(III). The rates of reduction of the high valent species were zero orderwith respect to [Am(VI)] and any effect of hydrogen ion concentration was thought to be small. Hall and Markin (1957) later reported similar kinetics. The authors attributed this autoreduction to the $\mathrm{H}_{2} \mathrm{O}_{2}$ product of americium alpha decay. All this early work was performed in $\mathrm{HClO}_{4}$ solution presumably using ${ }^{241} \mathrm{Am}$, and similar investigations of americium reduction kinetics in $\mathrm{HNO}_{3}$ have not been reported. 
Since Am(VI) is now routinely prepared over a wide range of nitric acid concentrations using sodium bismuthate, that approach was used here to measure autoreduction kinetics over a range of $\mathrm{HNO}_{3}$ concentrations. The reduction was followed by UV/Vis spectroscopy, using tracer americium in the 100-cm liquid waveguide capillary cell (LWCC), and using higher americium concentrations in a standard 1-cm cell. The higher data quality found when using the $1-\mathrm{cm}$ cell in conjunction with the Cary 6000 instrument resulted in the abandonment of the LWCC for future reduction kinetics measurements. In addition, the reductive effects of contact with organic solutions and various system structural materials commonly encountered in fuel cycle separations were also investigated, using solvent extraction distribution ratios.

These findings, in conjunction with the results of the FY13 cold test, were used to design a hot test bed. This test bed was constructed in a posted contamination area-fume hood, and consisted of three stages of centrifugal contactors, with stage 1 being the extraction, stage 2 being an americium strip, and stage 3 being a cerium strip. This is the first demonstration of hexavalent americium extraction using a continuous, process-like test bed.

\section{SUMMARY OF RESULTS}

\subsection{Hexavalent Americium Stability}

The full results of the investigation into Am(VI) stability were reported in a manuscript submitted for publication, in fulfillment of program milestone number M2FT-14IN030031 requirements (Mincher et al. 2014). Only the main conclusions are summarized here. It was clearly demonstrated that a self-consistent set of extinction coefficients for the various americium species over a range of nitric acid concentrations is needed. If accurate concentrations cannot be calculated for the various americium species based on their UV/Vis absorbances, then neither can reduction rate constants be accurately calculated. However, several conclusions about Am(VI) autoreduction may be postulated. These include that the most precise measurements will be made using millimolar americium concentrations in a 1-cm cell and with the Cary $6000 \mathrm{UV} / \mathrm{V}$ is spectrophotometer for data acquisition. The autoreduction of Am(VI) in 6.5 $\mathrm{M} \mathrm{HNO}_{3}$ using this equipment and data acquisition is shown in Figure 1. The most important conclusion to be drawn is that at millimolar americium concentrations, Am(VI) is stable enough against its own autoreduction for separations purposes.

The lack of dependence on nitric acid concentration suggests either that $\mathrm{HNO}_{2}$ is not an important reducing agent toward $\mathrm{Am}(\mathrm{VI})$, or that $\mathrm{HNO}_{2}$ is a low yield $\alpha$-radiolysis product of nitric acid. Hydrogen peroxide was shown to readily reduce Am(VI) but not Am(V), in contrast to predictions based on the published rate constants for the reaction of $\mathrm{Am}(\mathrm{V})$ and $\mathrm{Am}(\mathrm{VI})$ with $\mathrm{H}_{2} \mathrm{O}_{2}$ (Zaitsev et al. 1960; Woods et al. 1974). The determination of the rate constants for the reactions of $\mathrm{Am}(\mathrm{V})$ and $\mathrm{Am}(\mathrm{VI})$ with $\mathrm{HNO}_{2}$ and $\mathrm{H}_{2} \mathrm{O}_{2}$ would also be valuable future work. As expected, organic compounds act as reducing agents toward Am(VI), and also Am(V). This agrees with previous flowsheet development work (Law et al. 2014) that suggested that additional extraction cycles may require reoxidation. An important area of future investigation will be investigating the efficiency of the re-oxidation of previously treated americium solutions. 


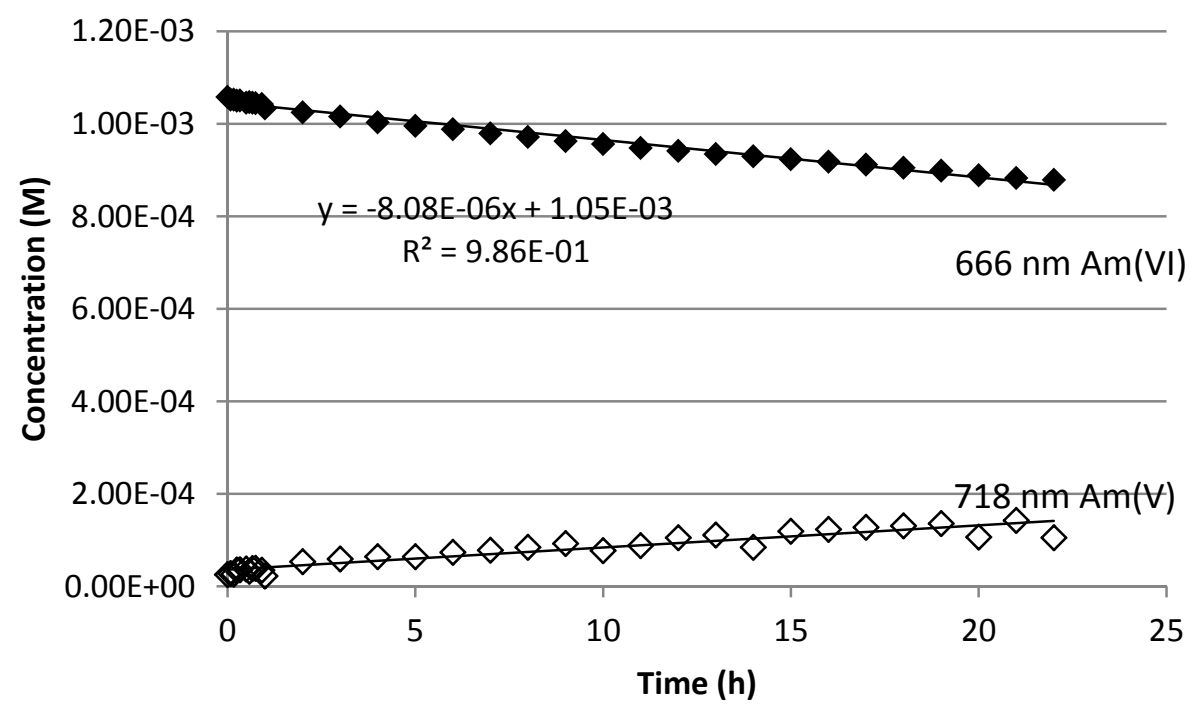

Figure 1. The autoreduction of $\mathrm{Am}(\mathrm{VI})$ in a $6.5 \mathrm{M} \mathrm{HNO}_{3}$ solution containing $2 \times 10^{-3} \mathrm{M}$ total Am, based on the absorbance measured for Am(VI) at $666 \mathrm{~nm}$ (closed diamonds), in a 1-cm cell using the Cary 6000. Rate constant based on the mean of linear fit for the entire data set is 0.004 $\mathrm{h}^{-1}$. Using the fit to only the first ten hours a rate constant of $0.005 \mathrm{~h}^{-1}$ was obtained.

\subsection{Hot Test}

A major accomplishment during FY14 was the hot test. Americium oxidation and extraction was performed using a centrifugal contactor-based test bed consisting of an extraction stage and two stripping stages. Based upon batch contact results, flowsheet design and a previous cold test, a hot test bed was successfully designed, built and operated in a radiological fume hood at CFA at INL. The work is described in detail in an FY14 FCR\&D report SWF-2014-000218 (Mincher et al. 2014b), in fulfillment of milestone M3FT-14IN0303033. An ${ }^{243} \mathrm{Am} /{ }^{139} \mathrm{Ce}$-spiked raffinate simulant feed was oxidized with sodium bismuthate, filtered through a Teflon filter, and fed into a custom built CINC 5-cm centrifugal contactor, made of materials determined to be inert toward Am(VI). Sixty-three percent americium extraction was obtained in one stage using $1 \mathrm{M}$ DAAP/dodecane, in agreement with batch contacts. This demonstrates for the first time that Am(VI) can be extracted using process equipment. Although Am(VI) was also expected to be easily reduced and stripped based on batch contacts, the short residence time apparently made stripping ineffective. This finding is fortuitous in that it should now be possible to design a scrub contact into the flowsheet, which was previously thought to be impossible due to undesired americium reduction and stripping during batch contact scrubs. Cerium stripping using $0.3 \%$ $\mathrm{H}_{2} \mathrm{O}_{2}$ was also inefficient, in spite of the success of that strip during cold testing. This is again attributed to residence time of the contact. However, selective stripping should still be possible, given either longer residence times in contact with the organic phase, or more aggressive reductants in the strip solutions. The centrifugal contactor and filtration system employed in this test is shown in Figure 2. 


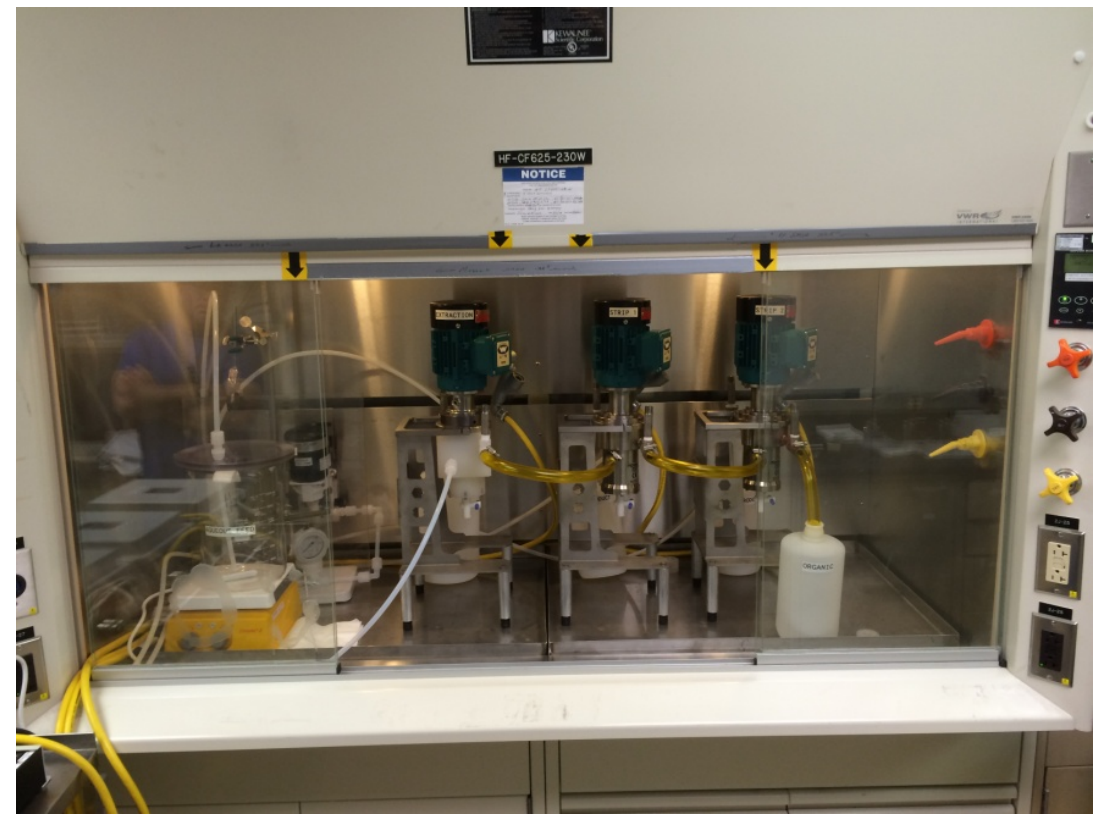

Figure 2. Hot hood showing the three stage centrifugal contactor test bed, simulant feed reservoir and bismuthate filter. Note: The system was photographed prior to taking it hot and therefore, there are no Contamination Area postings on the hood.

\subsection{Americium Electrochemistry}

Promising results with a high surface-area, fluoride-doped tin oxide (FTO) electrode, coated with nano-particles of tin-doped indium oxide (nITO) have been obtained. The surface was derivatized with a terpyridine ligand for binding of Am(III). At an anodic potential of $1.8 \mathrm{~V}$ vs. $\mathrm{Ag} / \mathrm{AgCl}(\sim 0.8 \mathrm{~V}$ below the $\mathrm{Am}$ (III/IV) redox couple) in a $0.1 \mathrm{M}$ nitric acid/0.95 M sodium nitrate solution containing $0.4 \mathrm{mM}$ total americium, approximately $50 \%$ of the Am(III) was oxidized to Am(V) over the course of 1 hour as observed by UV/Vis spectroscopic measurements. The multi-electron oxidation of Am(III) is believed to be facilitated by coordination to the surface bound terpyridine ligand. It is believed that this is the first demonstration of the electrolytic oxidation of americium in a non-complexing solution. These results were presented in more detail in fulfillment of milestone M4FT-14IN0303032.

\subsection{Butryamide Extractions}

An initial investigation of $\mathrm{Am}(\mathrm{VI})$ extraction using two butyramides; diethylhexylbutyramide (DEHBA), and diethylhexylisobutyramide (DEHiBA). Of these, DEHBA had the better performance. Similarly to DAAP, the highest distribution ratios for oxidized americium extraction occurred at 6-7 $\mathrm{M} \mathrm{HNO}_{3}$, being slightly above 1 . The mixture of $1 \mathrm{M} \mathrm{DEHBA} / 1 \mathrm{M}$ TBP provided $D_{\mathrm{Am}} \sim 4.7$. According the literature, the butyramide dihexylhexanamide may provide still higher extraction efficiency at lower concentrations, and is worthy of further investigation (Pathak et al. 2000). A benefit of this approach is that the butyramides do not seem to be as reducing toward Am(VI) as is DAAP. 


\section{REFERENCES}

Asprey, L.B.; Stephanou, S.E. 1950. The autoreduction of Am(VI) and Am(V). United States Atomic Energy Commission Report AECU-924. Los Alamos Scientific Laboratory.

Hall, G.R.; Markin, T.L. 1957. The self-reduction of americium(V) and (VI) and the disproportionation of americium(V) in aqueous solution. J. Inorg. Nucl. Chem. 4: 296-303.

Law, J.; Mincher, B.; Garn, T.; Greenhalgh, M.; Schmitt, N.; Rutledge, V. 2014. Development and testing of an americium/lanthanide separation flowsheet using sodium bismuthate. Proceedings of ICAPP 2014, Paper 14040.

Mincher, B.J.; Schmitt, N.C.; Grimes, T.S. 2014. The persistence of Am(VI) in nitric acid solution. Solvent Extr. Ion Exch. submitted.

Mincher, B.J.; Tillotson, R.; Law, J.; Garn, T.; Schmitt, N. Sodium bismuthate process: Oxidation test bed setup and hot testing. FCR\&D Report SWF-2014-000218. Sept. 30, 2014.-

Mincher, B.J.; Martin, L.R.; Schmitt, N.C. 2012. Diamylamylphosphonate solvent extraction of Am(VI) from nuclear fuel raffinate simulant solution. Solvent Extr. Ion Exch. 30: 445-456.

Pathak, P.N.; Prabhu, D.R.; Manchanda, V.K. 2000. Distribution behaviour of U(VI), Th(IV) and $\mathrm{Pa}(\mathrm{V})$ from nitric acid medium using linear and branched chain extractants. Solvent Extr. Ion Exch. 18, 821-840.

Woods, Sr., M.; Cain, A.; Sullivan, J.C. 1974. A kinetic study of the reduction of americium(VI) by hydrogen peroxide in aqueous perchlorate media. J. Inorg. Nucl. Chem. 36, 2605-2607.

Zaitsev, A.A.; Kosyakov, V.N.; Rykov, A.G.; Sobolev, Yu. P.; Yakolev, G.N. 1960. Kinetics of Americium(V) reduction by hydrogen peroxide. Radiochemistry 2, 348-350.

\section{PUBLICATIONS AND OTHER INDICATORS OF PROJECT QUALITY AND PRODUCTIVITY}

Mincher, B.J.; Schmitt, N.C.; Tillotson, R. D.; Elias, G.; White, B.M.; Law, J.D. 2014. Characterizing diamylamylphophonate (DAAP) as an americium ligand for nuclear fuel cycle applications. Solvent Extr. Ion Exc. 32:153-166.

Moyer, B.A.; Lumetta, G.L.; Mincher, B.J. 2014. Recent advances in the USA in minor actinide separation. Ch. 9 in: Reprocessing and recycling of spent nuclear fuels, Woodhead Publishing Limited. In review.

Law, J.; Mincher, B.; Garn, T.; Greenhalgh, M.; Schmitt, N.; Rutlegde, V. 2014. Development and testing of an americium/lanthanide separation flowsheet using sodium bismuthate, in: Proceedings of ICAPP 2014, Charlotte, NC. 


\section{COLLABORATORS AND PARTICIPANTS}

1) Bruce Mincher, INL, PI.

2) Nicholas Schmitt, INL, staff collaborator, solvent extraction and UV/Vis experiments, autoreduction kinetics, hot test support.

3) Richard Tillotson, INL, staff collaborator, solvent extraction experiments, hot test support.

4) Lonnie Olson, staff collaborator, DAAP irradiation, hot test support.

5) Jack Law, INL, staff collaborator, flowsheet design, hot test support.

6) Troy Garn and Mitch Greenhaulgh, INL, staff collaborators, hot test support.

7) Travis Grimes, INL, staff collaborator, autoreduction kinetic measurements.

8) Tom Meyer, UNC-Chapel Hill, and PostDoc Chris Dare, Am electrochemistry research funded via INL participation in sigma team.

9) Gregg Lumetta, PNNL, $\mathrm{Cu}$ (III) oxidations. Funded through independent sigma team program. 